\title{
The Revival of Family Capitalism
}

\section{A Zhejiang entrepreneur}

\section{Gilles Guiheux}

\section{OpenEdition}

\section{Journals}

Édition électronique

URL : http://journals.openedition.org/chinaperspectives/461

DOI : $10.4000 /$ chinaperspectives.461

ISSN : 1996-4617

Éditeur

Centre d'étude français sur la Chine contemporaine

Édition imprimée

Date de publication : 1 avril 2005

ISSN : 2070-3449

\section{Référence électronique}

Gilles Guiheux, «The Revival of Family Capitalism », China Perspectives [En ligne], 58 | march - april 2005, mis en ligne le 01 avril 2008, consulté le 28 octobre 2019. URL : http://journals.openedition.org/ chinaperspectives/461 ; DOI : 10.4000/chinaperspectives.461

Ce document a été généré automatiquement le 28 octobre 2019.

(C) All rights reserved 


\title{
The Revival of Family Capitalism
}

\author{
A Zhejiang entrepreneur
}

\author{
Gilles Guiheux
}

Promoting exemplary models of economic organisation is a tradition in communist China: Most famous among such models are the commune of Dazhai in Shanxi province and the city of Daqing in Heilongjiang, which have been models for rural and urban China since 1964-19651. During the 1990s, while China's market economy was strengthening, state-owned enterprises were required to follow the model of their Japanese or Korean counterparts, with the aim of creating "national champions" 2 . More recently, Hai'er, based in Qingdao in Shandong province, and which originally manufactured household appliances, has had wide praise in the media. The history of its development is the subject of several reports available in any bookshop nationwide ${ }^{3}$. Hai'er is shown as the Chinese equivalent to General Electric in the United States, or Sony in Japan; as a Chinese international (Hai'er has industrial plants in the United States), it is a new model.

2 This article deals with another type of economic organisation, less conspicuous and less newsworthy, but on the increase in China: the private family firm ${ }^{4}$. Our analysis is based on the statements of an entrepreneur, Mao Lixiang, head of the Feixiang group, whose main company, Fangtai (Fotile is the English name) manufactures kitchen equipment ${ }^{5}$. Our study of this exemplary firm is rooted in observable practices as well as in the words of the very creator of the business. I chose this particular businessman because of the visible and coherent quality of his speech. Mao has written several books about his own experience, which appear as initiation handbooks for prospective businessmen ${ }^{6}$. Mao often gives interviews to the media (written press, television or radio) and takes part in fora all over the country. He has thus become a public figure. His speeches, as well as his practices, are also validated by management professionals. Mao is regularly asked to intervene in the training programmes of top universities, particularly in MBAs (Masters of Business Administration), at Peking and Tsinghua universities. A public figure, Mao dedicates a part of his time, a third according to him, to promoting family business across the country ${ }^{7}$. The number of social stages held by 
Mao Lixiang indicates that, in China today, private businessmen have the opportunity to speak their minds, and thus have increasing influence ${ }^{8}$.

In China, on entering a bookshop and glancing at the titles on the shelves, one is impressed by the number of translated works, from Bill Gates (Microsoft), Lee Iaccoca (Chrysler) to Akio Morita (Sony): the gurus of management are mostly foreigners9. Looking more closely at Mao Lixiang is like looking into the case of a guru, a guru not quite as famous as others and Chinese. If Zhang Ruiming, the chairman of Hai'er, may be considered by major Chinese companies as the model to be followed, Mao Lixiang has a similar role for the family business ${ }^{10}$. He embodies part of the country's modernist economic elite and champions their interests (in as much as the regime allows them freedom of expression). For that matter, he is known as such by the political authorities ${ }^{11}$. Indeed, it is not easy to tell how effective his speech is-stating principles is not enough to convince-, but his ability to express himself through various media, management literature, the general public press, the field of politics, is proof enough.

Through an analysis of the way Mao Lixiang speaks of his personal career, of family firms and of the Chinese economy in general, our aim is to identify the new ideological and moral order that is in progress in China today. Actually, if the People's Republic offers the main characteristics of a capitalist economy (the merchandisation of labour, privatisation of the means of production, the emergence of a class of businessmen), individualism is rejected as a "bourgeois" value ${ }^{12}$, and the reforms have been justified in terms of socialism-the Party has introduced the notion of "initial step of socialism" ${ }^{13}$. However, changing successfully from a planned economy to a market economy implies an ideological transformation. The present article focuses on identifying the new standards and the new values that make up both the basis and the effect of such a transition. In the background of Mao's defence of family business, what is in question is not only economic action in all its forms, but also the personal enrichment of a few and the emergence of a new social stratification (Mao's personal fortune is estimated at near to 100 million yuan ${ }^{14}$ ).

5 In a Weberian viewpoint, acknowledging the crucial part played by the values and mission of the institutions, Mao's practices and speech are read as indicators of the Chinese "spirit of capitalism". I am assuming that the documents this study is based on (Mao Lixiang's books, newspaper articles, interviews) offer standards and meaning and develop arguments in favour of the economic functioning in the world of business and in the inner working of the firms. The speech in question is part of the discourse that legitimates the economic and social system being established for the last twenty years ${ }^{15}$. Even though the building-up of a new legitimate economic and social order also implies the use of violence, since one remains in a single-party system that allows no pluralism, particularly where trade unions are concerned, I have chosen to take seriously the ideological constructions that go along with the transition.

A career embedded in a specific territory

6 Mao's speech takes on meaning as part of a long professional career across a territory, the north of Zhejiang province, between the cities of Hangzhou and Ningbo, where a network of small and medium-size businesses started to develop as early as the 1960s. After 1978, Mao's career follows the institutional changes involved in the politics of reform and opening up led by the central government.

7 Mao Lixiang was born in 1942 into a poor family from Cixi, about sixty kilometres west of Ningbo ${ }^{16}$. On leaving secondary school, he entered professional life as a teacher and 
taught for two years. In 1965, at 23 , as a young man he became an accountant for a commune and brigade enterprise (shedui qiye) ${ }^{17}$, where he stayed until 1974 . Until 1994, he was responsible for the firm's sales; the factory employed about forty people and was a subcontractor, making parts for Shanghai state-owned car industry and radio-set enterprises. In fact, the city of Cixi, in the second half of the 1960s, was an area of rapid development for this type of business. The number of small town businesses rose from 19 in 1964 to 106 in 1970 and reached 186 in 1974, with no notable change in the demography of other types of businesses ${ }^{18}$.

A township and village enterprise within the contract responsibility system

In 1985, Mao became the manager of a factory located near Cixi, in the zhen of Zhanghe, "factory number 9 producing radio parts". Officially, it was a collective owned by the local government and subcontracting pieces for Shanghai TV-set manufacturers. The local administration put up the money for the purchase of the first six machines. The working capital, hardly 2000 yuan, was brought by Mao himself ${ }^{19}$. As a matter of fact, the business is granted to Mao within the limits of the contract responsibility system (chengbao hetong). The system, also set up for the peasants' homes as a part of decollectivisation, takes the shape of a contract between the business manager and the administrative unit he is attached to (here, between Mao and the Zhanghe zhen). The contract sets the yearly rent that the firm has to pay to its administrative unit, in return for which the manager is master of his own firm. The firm is de jure collectiveconsequently entitled to the privileges granted to any business controlled by local authorities (particularly when it comes to obtaining credit)-, it is a de facto private firm. Within the firm, Mao understands the responsibilities: "I am, at the same time, the Chairman of the board of directors, the general executive and the sales manager" 2 . In 1986, overproduction has sent the market into crisis. Within a few months, Mao loses his customers, and looked for another type of production ${ }^{21}$. Following a friend's advice, he goes to Xinyang (Hunan province) and visits a manufacturer of measuring instruments who is supposed to have invented a new product. But when Mao gets there, the information proves wrong. From Xinyang, he goes to Peking, to the Electronic Techniques Research Institute. There, a friend shows him another product, an electric fire-lighter (dianhuoji); Mao decides to start manufacturing this item. Setting-up the new production lines takes only forty-five days.

The new product gets a good reception from the market. Mao sends his salesmen all over the country, going himself to the big cities, Peking and Shanghai. He is awarded the "Golden Eagle Prize" by Zhejiang province, a prize to reward creative business ${ }^{22}$. The product is exported, first through an international business company, from 1986 to 1989, then directly. In 1989, Mao takes part in the Canton Fair for the first time and signs his first contracts with foreign customers ${ }^{23}$. The firm, the first Chinese manufacturer of fire-lighters, is quoted among the top hundred exporters from Zhejiang province, and has become one of the few first national small town businesses doing export trade. Mao is given the nickname of "worldwide king of the electrical firelighter". In 1992, the firm changes its name and becomes the Feixiang Group (Feixiang jituan). Between 1986 and 1992, the number of employees increases tenfold, from 100 to $1,000^{24}$. However other businesses start manufacturing the same products in Cixi and in the neighbouring places of Ningbo and Yutao. The competition between manufacturers sends prices tumbling.

A new private firm 
11 In 1995, Mao Lixiang invests 5 million yuan a new business, Fangtai ${ }^{25}$. The firm is established with the legal status of a public limited corporation; it is a joint stock company of which Mao's family owns $80 \%$. Mao is chairman of the board of directors (dongshizhang), his wife is president of the observation committee (jianshehui zhuxi), and his son, Mao Zhongqun, is executive manager (zongjingli). No other member of the family is employed. Betting on improvements in housing conditions in Chinese cities, the new firm starts manufacturing extractor hoods for the kitchen; it later diversifies into manufacturing kitchen facilities and furniture.

12 Mao Lixiang's professional career entitles him to the position of spokesman that he has. His activities developed gradually; from subcontracting for big Shanghai companies to manufacturing and trading under his own brand, while building up a wealth of experience, a capital of acquaintances, abilities and resources all of which were made to work for the economic growth of his activities. Contrarily to those who, in China over the last twenty years, have made a fortune at the stock exchange or in real estate, Mao may look upon himself as a genuine entrepreneur who has created products, settingout to conquer new national or international markets.

13 Secondly, Mao's career has logically found a place in the records of institutional changes over the last two decades. For twenty years, from 1965 to 1985, Mao worked as a salaried employee of a collective business owned by the local government. He then set up on his own within the bounds of the contract responsibility system, the only option in the mid-eighties. The firm was officially a collective, but Mao had to supply the capital and was also responsible for profits and losses. The public feature was just for show, since Mao only "displayed the state label" (guale gongjia de paizi) ${ }^{26}$. Ten years later, after the Company Law was passed in 1993, Mao set up a private-rights company with profits from his previous activities ${ }^{27}$. Equally helpful was his past as a sales manager for a small town enterprise (from 1974 to 1994): "Those were difficult years. At the time, the economy was planned, but we were allowed no raw materials. Materials were given to state-owned firms, and their sales were warranted; but we had no guaranteed supplies; we had to find our raw materials and our market" ${ }^{28}$. Managing a small town enterprise responsible for its profits and losses enabled Mao to acquire the skills necessary for a business manager in a market economy.

14 By 1995, Mao already had thirty years of experience of doing business in Cixi, so his decision to establish Fotile here is not surprising. The continuity between his various firms is not through their activities, rather to the command of a technological skill, since they go from manufacturing parts for TV sets to manufacturing fire-lighters and then kitchen facilities, all of them simple products technologically speaking. In the accounts he gives of his business ventures, Mao in fact suggests that changing from one product to the other happened, so to speak, by chance while he also stayed in line with the local small mechanical and electric industry. Hence, as electric fans had been made in Cixi for twenty years, Mao decided in 1995 to start manufacturing kitchen extractor hoods. Over forty years, this is less the record of a firm than the record of an individual who successively managed several businesses with different legal status and different production. Their common feature is their manager ${ }^{29}$.

This is probably why Mao Lixiang never thought of setting up anywhere other than Cixi, a choice he justifies by the quality of the local industrial infrastructure. Indeed, the local prosperity is linked to a network of small and middle size enterprises that have been working for a long time as subcontractors for the big Shanghai industry. So, 
all the supplying of Fotile can be done locally; "whatever the part, it can be manufactured in Cixi" ${ }^{30}$. As a matter of fact, the small town businesses have played the greatest part in the development of the local economy between 1978 and 1987. In that lapse of time, their number went from 275 to 921 , while the value of their production multiplied by eleven. The firm produces mainly household appliances (electric fans in the 1970s and 1980s, ovens and irons in the 1980s and 1990s) and electric components for the Shanghai TV, car or electric appliances industries ${ }^{31}$. Today, the road from Ningbo to Cixi runs across a landscape now urban now rural and continuously industrialised. In the near future, the building of a bridge across the Hangzhou Bay should strengthen the link with Shanghai-once the bridge is in use, it will take less than an hour to travel from Cixi to Shanghai.

The firm and the market economy

At the end of his career, a career exemplary of the adjustment of a whole region to institutional changes, Mao Lixiang, today in semi-retirement, describes his own way of looking at business and at the organisation method of Chinese economy, at university conferences, in books on management, at business fora ${ }^{32}$, as well as in the media. This study is based on a selection of articles put together in order to "pass-on a worthwhile statement to the younger generations of entrepreneurs" ${ }^{33}$. Three main themes come to light in Mao's speech: the firm as an organisation, the market as a space of confrontation of the producers, and the necessary collaboration with the public authorities.

The firm as an organisation

Mao deals with the firm as an organisation from two angles: the manager's responsibilities and the part he/she plays; and the rallying of employees to serve the organisation's interests. The entrepreneur appears as someone who must be both solitary and creative. He must "keep away from the world" (chaotuo), a phrase with a triple meaning: "Turn one's mind away from day-to-day matters in order to apply one's energy to major problems; reject common ideas in order to think differently, creatively; pay no heed to the commonplace in human relationships (renji guanxi)" 34 . The entrepreneur's aloneness (gudu) is a guarantee of his ability to break new ground. "Innovation, this is where the company's vitality is" ${ }^{35}$. Not only does this characterise the boss; it should also distinguish each and every employee; this is one requirement is found in a slogan of Fotile: "Be sincere, respect the company, study, innovate" (zhengcheng, jingye, xuexi, chuangxin). Innovation, that is, not restricted to technology but extends to methods of organisation as well as the discovery of new markets ${ }^{36}$. There is a popularised version of Schumpeter's definition of the entrepreneur ${ }^{37}$. The insistence on the crucial part played by the head of the business fits in perfectly with and follows the direction of the reforms started in 1978, the aim of which was to make the firms and their managers responsible for their profits and losses. There, Mao Lixiang's ideas are utterly in keeping with all that was written and published in tribute to business managers as the heroes of contemporary Chinese society ${ }^{38}$.

The manager's solitariness has another meaning: it allows him to "pay no heed to the commonplace in human relationships" ${ }^{39}$. This is a call to give up what Mao elsewhere describes as "the methods of management characteristic of the previous step in the history of Chinese development". Aware of the pressures that human relationships have on economic life, Mao requires decisions to be made, from now on, heedless of 
these pressures. In short, he recommends the use of modern management methods against Chinese social traditions. He is saying that necessary economic modernity should break from the old social practices. The entrepreneur must be modern, as against what Marie-Claire Bergère has called "the old man" ${ }^{40}$. What Mao says can also be understood as the rationalising of a practice that can be observed in many a private family-business where actual power is fully in the hands of the entrepreneur, a charismatic authority.

In addition to the question of its management, the firm is considered a human community; according to Mao, its major asset is man. "Modern management must consider man as its main resource"; it must "put the people first" (yiren weiben) ${ }^{41}$. This is in keeping with the transition from the planned economy, when firms were entirely involved in their task of production (and when staff management was strictly a bookkeeping and administrative matter), to the market economy in which what has become important is staff motivation and in which success is determined by the efficient management of men. It is from this viewpoint that Mao's passages about the necessity to build a firm as a community of men focusing on common aims, hence the importance given to the idea and practice of creating a team-spirit (tuandui), or the necessity of "together building the Fangtai spirit" (gongzhu Fangtai hun), ${ }^{42}$ and a corporate culture (qiye wenhua). What has to be created in the employees is the feeling that they belong to the company.

The phrase "putting the people first" is also inspired by Confucian thinking and suggests the benevolent attitude the manager must have towards his employees, similar to that of the prince towards his people ${ }^{43}$. Moreover, in the importance placed on people as a resource of the firm, there is somewhat of a "socialist" echo. Mao Lixiang does not discard a certain rhetoric inherited from the time of the planned economy and from the work units acting in the economic, social and administrative fields. Mao thus appoints the firm to "come up to the employees' material, spiritual and affective needs, and to set up relationships of confidence and equality between individuals, in order to guarantee the working and vitality of the firm in the long run" 44 .

In another passage, Mao insists on "permanence" in contemporary Chinese economy and society, of supposedly traditional values, particularly loyalty and sincerity (zhongcheng). "Traditional Chinese culture particularly insists on loyalty and sincerity. The zhong character in Confucian culture means loyalty towards the Emperor, loyalty towards the feudal sovereign, the vassals must die for their sovereign-they can but die -, the son must help his father-he can but help his father. That unquestioning loyalty allowed the feudal political system to be maintained for 2,000 years (...). In modern management, loyalty and sincerity must be a principle of behaviour for employees (...). Modern loyalty-we must consider it from the point of view of the market, we must use it, and everybody should try to be loyal towards the group, towards the company" ${ }^{45}$. In other words, Mao reinvests a supposedly traditional notion with a new meaning.

The market

22 Mao Lixiang's speech gets organised around a second theme, market as a space of confrontation between the producers. It is, in fact, the idea of competition that Mao chooses to characterise market economy: "The market exists, anyone may take part in it (...). The market is like white rice, and the firms are like hens and ducks [trying to eat the white rice] (...) Competition in the market is something positive, it is only through competition that society can progress" ${ }^{\prime 4}$. Mao thus words a popularised version of 
liberal theory; the free competition of individual interests (the individual being the firm) produces common good.

Mao emphasises that firms should find and keep a trademark, the very condition of the reputation of their products and consequently of their success. Mao illustrates his statement by giving as examples foreign trademarks (Coca-Cola, Pepsi-Cola, 555, Pierre Cardin) as well as Chinese ones (Wahaha, Hongtashan, Hai'er, Changhong). Adopting a trademark is all the more important as Chinese products, in the future, will have to face growing competition from foreign producers now China is a member of the World Trade Organisation ${ }^{47}$. The notion of a mark (pinpai) in fact reappeared with the 1978 reforms. During the Maoist period, products did not bear labels, just the references of the factory where they had been manufactured (indications of the place and often a number), other than a few companies already well established before 1949.

Together with the importance of the trademark, Mao mentions the practices of imitation, to declare that imitation is "a malignant tumour"48. In another passage, he talks of "orderless competition (wuxu jingzheng) [which] allows firms and trades people who do not create products, do not use advertising and do not set up sales networks, to make a lot of profit in a very short time". He quotes the case of his own activity:" At the beginning, in Cixi, there were only two plants manufacturing extractor hoods (...). But once the media had reported "the Fangtai phenomenon", there were more than ten establishments" ${ }^{\prime 9}$. Since then, Fangtai has been equipped with a legal department, partly to fight that curse. But, Mao thinks, firms pay their due taxes and are in a position to require from local authorities that they protect them "in accordance with the law". So Mao wishes for a local state that would be more helpful in the enforcement of the law, a guarantor of order on the market.

Firms and local governments

Mao Lixiang considers, indeed, that the state is an indispensable partner of businesses. In China, entrepreneurs "can only rely (bang) on the government" 50 To the question "must we run after the market or must we run after the mayor?" of course "the market is very important, but you absolutely can't forget the mayor. As a matter of fact, the links between the Chinese economy and the government are very strong. You can't do without calling for the mayor! Our market economy is only emerging, it is still in a phase of development, the competition on the market is often disorderly, you have to rely on the government to co-ordinate [the companies' actions on the market]. When laws or rules are issued, it takes some time before companies adjust to the new environment, and there too the government has to play the part of co-ordinator (xietiao). Local rules are too numerous; if you want to develop you can rely only on the government's help. Labour is also a matter of concern, social relationships (shehui guanxi) are also matters that can be solved only with the government's help. Many say you have to run after the market not after the mayor. Not to seek the mayor's help is a harmful mistake!" ${ }^{52}$. In the transition that characterises the Chinese economy, between the planned economy and the market economy considered not quite achieved, a relationship of co-operation between businesses and the local administration seems indispensable, in Mao Lixiang's opinion; and the main reason he puts forward is the disorder that characterises today's market, a result of the inadequate legal and statutory system.

If Mao considers relying on the local governments as necessary, he nevertheless underlines the dangers of such co-operation. "While you rely on the authorities, you 
might fall into a situation which it would be very difficult to get out of, or, to borrow a popular phrase, you might become a government supporter, and then you wouldn't be able to develop any further"53. Here, Mao implies the danger of too close a proximity which, instead of benefiting the firm, would on the contrary prove harmful; the firm would appear an accomplice of local authorities collecting excessive taxes from the companies in their district". Authorities, exactly like family members, may become predators in the company: "Running a company is a difficult task (...). The fire department, the labour office, the commerce and industry bureau, the land bureau, the protection of nature office, the tax department, they all come and see you (...). If the business manager makes a profit, his brothers, relatives, friends, neighbours, school fellows, all come and call on him" ${ }^{54}$.

At the end of this first clarification, three types of rhetoric can be identified in Mao's speech on business and the market. The first mentions modernity associated with a market economy, the second refers to Chinese tradition, and the third bears the mark left by thirty years of a planned economy. Conversion to the benefits of the market is indicated by the increase in value of competition, of innovation, of the manager's daring, of corporate culture, of employee ability or of the importance granted to marketing. In the same way, referring to exemplary entrepreneurs-whether they are Americans like Lee Iaccoca, the former chairman of Chrysler ${ }^{55}$, Japanese like Akio Morita, the chairman of Sony ${ }^{56}$, or Chinese like Zhang Ruiming of Hai'er ${ }^{57}$, makes room for China in a globalised economy where all companies are defined according to the same criteria of efficiency. Tradition, when it is called up, shows positive dimensions that must be perpetuated-employee loyalty towards their employer-, and negative dimensions that must be given up-the importance of social relationships seen as harmful for an efficient management. Explicit references to the past are always done to a pre-revolutionary past, that of a moral and social tradition.

In the importance given to the relationship to the government, one can find the implicit mark left by thirty years of a planned economy. Mao reiterates his beliefs that the Chinese market economy is incomplete and insists on its imperfections. He calls for a more predictable and institutionalised state, co-ordinating enterprise actions, taking up the point of view of certain economists close to the Chinese leadership ${ }^{58}$. Not to be found in these comments is the Communist Party, of which Mao Lixiang has nevertheless been a member since 1991. But it does come to light in Mao's nationalistic rhetoric: Mao greets the success of Hai'er and wishes to turn his own business into a "national industry" (minzu gongye), with markets both at home and abroad ${ }^{59}$. While stating his ambitions, he takes up on his own account the Party's aims to rebuild a great and powerful country. This entrepreneurial nationalism sounds like state nationalism with its long history in China. Kept out are the workers, except through the theme of rallying the labour-force into teams and creating a corporate culture capable of stirring a feeling of membership and loyalty.

Defence and illustration of the family firm

In addition to delivering a general speech on the aims and constraints of entrepreneurial action, Mao Lixiang writes in defence of the family business (jiazu qiye), a pro domo plea. In fact, this type of organisation of the economic activity raises quite some interest today, whether from the media or from universities. Over the last ten years, the private sector, mostly made up of private businesses (a feature shared by many other economies) has become one of the engines of the Chinese growth. The 
media, as indeed specialists, underline the need to find solutions to four urgent issues: handing over from the founders' generation, the professionalisation of the management (is the reliance on family members still practicable?), the technological upgrading of enterprises (whereas small and medium-size enterprises are mostly labour-intensive), and the impossible resort to banking credits (and to informal financial sources) ${ }^{60}$. More generally, the issue at stake is the sustainability of the family enterprise as a Chinese economic growth engine. After reviewing the case of Fangtai, the article analyses the defence and illustration of such a case as written by Mao Lixiang.

Fangtai, a family business

30 In 1985, at the time of the founding of his business within the contract responsibility system, Mao Lixiang is at the same time the general manager and the sales manager. In order to "improve the management of the firm", he offers his wife, then the production manager of a textile plant and a specialist in management and finance, deputy managership of the firm. It is understood that "no-one else in the family could enter the business and hold a position of responsibility" ${ }^{6}$.

In 1995, when Fotile is established, Mao justifies appealing to his family by the risk he is running: "The risks are great. At that time, no-one wants to invest with us, only my wife, my son and daughter agree to support the project" 62 . His son, Mao Zhongqun, just graduated from the electric engineering department of Jiaotong University in Shanghai, was asked to take a direct part in the management of the business. Mao's daughter and son-in-law are contributing to the capital-they hold $12 \%$ of Fangtai ${ }^{63}$. They are the managers of their own business and will become parts suppliers-first producing parts for the manufacture of electric fire-lighters, and then producing fans for extractor hoods.

Mao Lixiang and his son both claim there was a negotiation between father and son, the latter only joining his father in his new industrial project (and giving up his personal project to do graduate work in the United States) under a two-fold condition: that the company be set up in an urban area, and that they manufacture a new product. Mao Zhongqun is supposed to have talked his father into setting up Fangtai in the economic development zone of the city of Cixi. He is also said to be who chose to manufacture extractor hoods. Both father and son thought the market of kitchen equipment promising, because of the growing consumer demand for home improvements. Mao Lixiang favoured manufacturing microwave ovens because the advanced technology involved would make obtaining financial help from the government easier. But Mao Zhongqun wished to start the manufacture of extractor hoods, a much simpler item.

Father and son also seem to have negotiated the choice of a name for the company. Mao Lixiang suggested Feixiang, a combination of his own and his daughter's given names, the latter being the name of his previous firm making fire-lighters. But his son preferred inventing a new mark. They finally choose a trademark imported from Hong Kong, Fangtai, borrowed from the name of a lady-presenter (Mrs Fang) of a very popular television programme produced in Hong Kong (by ATV channel), who is also the author of a cooking magazine (Dongfang shijie) sold all over south-east Asia. Concerning the place of manufacture as well as the company name, Mao's son seems to embody the break from the past, together with a more modern vision. business and the methods of power-sharing between himself and his son ${ }^{64}$. The co- 
operation between the two men progresses in three stages. First, between 1996 and 2000 , father and son worked closely together. The son worked on perfecting the manufacturing of new products while the marketing and the internal management are shared. Between 2000 and 2005, the father slowly retires from active management. The son is general manager and Mao Lixiang is chairman of the board of directors and declares he has totally retired from management of the company. Between 2006 and 2010, Mao Lixiang intends to give up his chairmanship to hold only the position of a member of the board of directors after which he will permanently retire.

From this account, one will remember the two arguments Mao gives to justify the family feature of the business: the risk involved (only members of the family are ready to share the risk); and skills. As far as skills are concerned, Mao's son presents all the possible potential: a graduate from Shanghai Jiaotong University in 1994, he gets a MBA from the Sino European Business School, China Europe International Business School (CIEBS), in 2002. Mao Lixiang, a charismatic manager whose figure is closely associated to his firm endeavours to show that he shares his power, at least with his son.

The three steps of the development of the family firm

Beyond giving an account of the establishment of his own business and of his management methods, Mao wants to be the champion of the family business in China. "There are some people, among economists and public administrations, who oppose the family system, they consider that it goes against modernity. But there are others who consider that, within the bounds of oriental culture, there is no getting away from a family system. When I lecture at Tsinghua, Beida or Beishida, many students ask my opinion on the family system. I answer them: 'today, it is impossible for Chinese private businesses not to be family businesses, but they should not be too much so'." 65 . Forestalling his detractors, Mao says he is in favour of the family business and that, at the same time, he is aware of the dangers of turning too often to that type of help (he held a similar position on the matter of proximity to local authorities: one can be near, but not too near).

Mao takes up again the arguments he develops about his own choices: not enough available abilities and skills, and too much risk. When setting up a business "only your wife and children can support you. It is the only possible choice". Thus you can but look for help from the family system (jiazuzhi). "If you do not use the family system, then no-one will want to get involved in such a fight [the establishment of a business]. Using your family, your relatives, your friends, your school fellows and your children, this is the best way to start" ${ }^{\prime 6}$.

Then, "private companies must give up their previous method of management and separate management from ownership, train the employees and look for new talent outside the establishment" ${ }^{67}$. You must then "lessen the family system" (tanhua jiazuzhi). If you do not lessen the family system, if you do not set up a modern management system, then there is no way to attract people of great ability into the company.

39 Mao insists on the need to separate management from ownership and to look for able managers; but until the level of confidence of employees is high enough, family management is still relevant: "The legal environment must still be improved, the technological quality of many managers as well as their moral qualities are not yet good enough; in an environment where confidence is missing (...). I have chosen my son to be my heir"68. Mao maintains that Chinese firms are halfway between the 
chandlerian business model run by managers and the model of traditional human relationships.

The case of Fotile does not exhaust the subject of the variety of firms in China today. It should be compared in particular with the firms that were directly inherited from the time of the planned economy, whether they are large state-owned corporations or collective firms. However, this defence of the family business deserves some attention because this type of organisations is a growing part of the Chinese economy.

41 Mao Lixiang's discourse on business and the market uses two styles of argumentation, one referring to the rationality of the market and the other to human relationships. The first is exemplified by practices that go in the opposite direction from those of a planned economy and are bound to spread: the creation and protection of trademarks that must be promoted, the constant use of innovation, the aggressive conquest of markets, the promotion of corporate culture, the rallying of competent managers. Human relationships are partly put aside-as obstacles to efficiency-and partly justified-the as yet indispensable part played by the family because of the lack of available ability and the inability to trust employees. In the same way, the need for the firm to have close relationships with the local authorities and with the state, is justified by the failings of the market, a market unable to play its part as a co-ordinator of individual initiatives, or by the general disrespect of regulations.

Such an account appears as a heterogeneous combination of arguments put together in favour of the cause of the managers of family firms. The use of a rhetoric at the same time modernist (the creative and solitary entrepreneur), socialist and Confucian (putting people at first) and traditional (the part played by the family) reflects a degree of opportunism.

Mao Lixiang considers these different arguments in light of his own interests and of those of his peers, the private entrepreneurs, and particularly those who have, as he has, first developed their career in the collective sector in the shelter of bureaucratic protections before setting-up their business on their own account. It is thus possible to ascribe Mao's arguments to the practical logic in which they were produced, to the real situation of their speaker and to his specific interests.

However, this discourse is not only about justification. The justifications expressed are useful to the capitalist transformations of the system in China. The references to foreign models are linked to the fact that Chinese firms are not only the suppliers of the global market but also faced directly with foreign competition in China itself. The insistence upon the professionalisation of management and the call for skilled people go hand in hand with the spread of management sciences in Chinese universities. The praise of the business-manager's qualities go hand in hand with the changes in legislation, particularly since private ownership has gained protection. The business manager's legitimacy is, from now on, subject to his professionalism. Likewise, Mao condemns an "orderless market" in which the rights of intellectual property are not respected and imitation is the rule.

Within the scope of an authoritarian state whose transformation is far from being completed, the institutions liable to rule competition or to structure the relationships between employers and employees are not yet established, and the nuclear family seems to be the institution the most capable of securing the economic modernisation of the country. This is in the line of an endless debate, initiated at the time of the first Chinese modernisation that deals with the credit due to the family as an institution 
made to serve the renewal of the Chinese nation ${ }^{69}$. More widely, the matter of the economic role of the state, or of the importance of personal links of confidence in business management, are well-known among specialists in the economic history of China $^{70}$. The originality of Mao Lixiang's discourse, when compared to that of this peers of the first twentieth century, may be in his call for the fast building of a regulating state, at a time when the latter tried to take the place of failing authorities ${ }^{71}$. Behind and beyond the record of a career and the speech for the defence of an entrepreneur, one finds a contribution to the building of a new economic and social order.

Translated from the French original by Geneviève Guiheux

\section{NOTES}

1. This article is a revised version of a paper read at the conference "Emerging Social Movements in China" co-organised by the Hong Kong University and the CEFC (Hong Kong, March 23rd-24th 2005).

2. See Peter Nolan, China and the Global Economy, Basingstoke and New York, 2001, Chapter 1, “China's ambitions: Building the 'national team"'.

3. For instance Yan Jianjun and Hu Yong, Hai'er. Zhongguo zao (Hai'er. Made in China), Hainan chubanshe, Haikou, 2001.

4. At the end of 2004, there are 3,750 millions firms registered as "private" (siying) in China (Mingbao, January 28th 2005, p. A32). Most of them are family businesses. It is the more dynamic part of the Chinese economy. To these "private" firms, we should add the "individual" ones (geti gongshanghu), that are also family-run and owned. On the definition of the private sector, see Gilles Guiheux, "The Incomplete Crystallisation of the Private Sector", China Perspectives, No. 42, July-August 2002, pp. 24-36.

5. Fotile manufactures kitchen range hoods, burners, water fountains and also kitchen furniture (see the firm's website: http://www.fotile.com). Fotile employs more than 3,000 people, control $15 \%$ to $20 \%$ of the Chinese market. It is the second biggest Chinese firm on that market (interview, July 23rd 2002).

6. Feixiang de guiji (Under the Influence of Fotile), Feixiang de guanli (The Management of Fotile), Feixiang de suiyue (The Fotile Years), Guanli qianqian jie (Management Principles).

7. During an interview carried in July 2002 in Cixi, Mao Lixiang used minqi to describe private enterprises ("the firms that belong to the people" and not to the state), which is more positive than siying qiye, the "privately run firms".

8. See Thomas Heberer, "Strategic Groups and State Capacity: The Case of the Private Entrepreneurs", China Perspectives, No. 46, March - April 2003, pp. 4-15.

9. Many MBA students in Chinese universities are aiming at internationalising their career and that might explain why many of the case studies concern foreign firms (besides the fact that foreign firms tend to make more internal information public). 10. In a scientific book on family firms (Gan De-an dir., Zhongguo jiazu qiye yanjiu (Research into the Chinese family business), Peking, Zhongguo shehui kexue chubanshe, 2002), Mao Lixiang is mentioned as an example of successful transmission of power from the founder generation to his son (p. 354). 
11. Mao Lixiang was for instance invited to take part in a conference with Premier Wen Jiabao at the end of August 2004 (21st Century Economic Herald, September 6th 2004, pp. 1-2). The "discussion forum to sustain the development of non-state economy" (feigong youzhi jingji fazhan zuotanhui) gathered nine private entrepreneurs from Zhejiang province.

12. See Wang Xiaoying, “The Post Communist Personality: The Spectre of China's Capitalist Market Reform", China Journal, No. 47, January 2002, pp. 1-17.

13. The phrase is first mentioned in 1981 and then systematically after the Thirteenth Congress of the Party in 1987. Zhao Ziyang then uses the concept of "socialist market economy" to justify the move from a planned to a market economy.

14. Chen Yan and Xu Xiaohui, Jiazu liliang (The force of the family), Zhejiang renmin chubanshe, 2003, p. 298.

15. Luc Boltanski and Eva Chiapello read the management literature as a discourse on French capitalism (The New Spirit of Capitalism, London, Verso, 2005). The material I am using is different in nature (they are not scientific textbooks), but they carry similar meanings. Jean Gadrey has underlined that articles from newspapers and magazines might be more typical of the "spirit of capitalism" and more efficient in spreading norms and producing meanings than the scientific literature (Jean Gadrey, "Nouvel esprit du capitalisme et idéologie néo-libérale", Sociologie du travail, $\mathrm{n}^{\circ} 43,2001, \mathrm{pp}$. 389-402). A common point between the texts analysed by Boltanski and Chiapello and my material is the public they are aiming at: future entrepreneurs or managers.

16. Cixi had 460,000 inhabitants in 1949, and around one million at the end of the 1990 (source: Cixishi gonganju bian, Cixishi gongan zhi (Annals of the public security of the Cixi city), Fangzhi chubanshe, Peking, 1998, pp. 251-253).

17. The growth of communes and brigade enterprises in the second half of the $1960 \mathrm{~s}$ can be partly credited to the lack of goods produced in urban areas, because of the Cultural Revolution forcing many enterprises to stop production. In 1984, the communes and brigades enterprises became "towns and villages enterprises" (WWWW, xiangzhen qiye). (William A. Byrd and Lin Qingsong (eds), China's Rural Industry. Structure, Development and Reform, Oxford, Oxford University Press, 1990, p. 11).

18. Cixi xianzhi (Annals of Cixi), Zhejiang renmin chubanshe, 1992, pp. 381-382.

19. Chen and $\mathrm{Xu}, \mathrm{p} .307$.

20. Mentioned by Chen and Xu, p. 300.

21. Mao Lixiang, Guanli qianqian jie (Management Principles), Zhongguo shangye chubanshe, Peking, 2002, pp. 34-37.

22. Ibid, p. 36.

23. The Canton fair (Zhongguo chukou shangpin jiaoyi hui, Chinese Export Commodities Fair) has taken place twice a year, in spring and autumn, since 1957.

24. Mao has probably taken advantage of the fact he was the first to produce such an article. That enabled him to make huge profits. Many towns and villages enterprises that are the first on a specific market (see W. A. Byrd, 1990, op. cit., p. 97).

25. Figure mentioned by Chen and Xu, 2003, op. cit., p. 303.

26. Source: interview.

27. On the gradual production of a legal framework for a non-state economy, see Gilles Guiheux, 2002, op. cit.

28. Source: interview.

29. Barbara Krug ed., 2004, China's Rational Entrepreneurs. The development of the new private business sector, London, RoutledgeCurzon. The industrial career of Mao fits 
Krug's description of the Chinese firm: "an evolutionary process in which the conditions for success and failure are laid down well before an actual firm comes into being" (p. 63).

30. Source: interview.

31. Cixi xianzhi, p. 382 and p. 393.

32. Mao is for instance member of the Research Centre on Family Enterprises of Zhongshan University, Canton.

33. Mao Lixiang, op. cit., p. 1.

34. Mao Lixiang, op. cit., pp. 10-12.

35. Mao Lixiang, op. cit., p. 57.

36. Mao Lixiang, op. cit., p. 59.

37. Schumpeter distinguishes five kinds of innovation: new products, new methods of production, new forms of organisation of the industry, new markets, new inputs. The Chinese press and media (such as Zhongguo qiyejia) have played a significant role in popularising the economic theory of entrepreneurship.

38. Not only in the media, but also in the literature or movies.

39. Mao Lixiang, op. cit., p. 12.

40. Marie-Claire Bergère, "Après Mao, le retour du vieil homme", Vingtième Siècle. Revue d'histoire, 1, 1994, pp. 31-45.

41. Mao Lixiang, op. cit., pp. 116-118.

42. Mao Lixiang, op. cit., pp. 136-141.

43. The same slogan yiren weiben is being used by the new Chinese leadership since the Fourteenth Party Congress (November 2002).

44. Mao Lixiang, op. cit., p. 116.

45. Mao Lixiang, op. cit., pp. 152-153, paragraph entitled "the meaning of "loyalty" for the market".

46. Mao Lixiang, op. cit., pp. 18-19.

47. Mao Lixiang, op. cit., pp. 244-248.

48. Mao Lixiang, op. cit., p. 256.

49. Mao Lixiang, op. cit., p. 18.

50. Mao Lixiang, op. cit., pp. 20-22. The term bang here translated by "rely" is put in quotation marks in the original text. It is used in every day language to designate a relation of dependency, such as a woman being kept by a rich man (WWW, bang dakuan).

51. In Chinese, the phrase is homophonic: zhao shichang haishi zhao shizhang.

52. Mao Lixiang, op. cit., pp. 313-314.

53. Mao Lixiang, op. cit., p. 20.

54. Mao Lixiang, op. cit., p. 331-332.

55. Lee Iaccoca is mentioned twice. Firstly for being a solitary leader (Mao Lixiang, op. cit., p.10), secondly because his career illustrates the separation between management and ownership (Mao Lixiang, op. cit., p. 175).

56. Mentioned about the necessity to build an enterprise culture (Mao Lixiang, op. cit., p. 138).

57. Mentioned in Mao Lixiang, op. cit., p.17 for his own personal qualities, and p. 139 about enterprise culture.

58. Fan Gang for instance, according to China is going through a transitional phase and is evolving towards a market economy similar to those characteristic of developed economies. 
59. Mao Lixiang, op. cit., p. 2.

60. See the three papers on family firms in the Blue Book of Private Enterprises [Zhang Houyi, Ming Lizhi and Liang Chuanyun (dir.), Zhongguo siying qiye fazhan baogao, vol. 4, Shehui kexue wenxian chubanshe, 2002].

61. p. 157.

62. p. 157.

63. pp. 165-166.

64. pp. 163-164.

65. p. 61.

66. p. 310 .

67. p. 160.

68. From Jinggji guancha bao, April 29th 2002.

69. See Susan L. Glosser, Chinese Visions of Family and State, 1915-1953, Berkeley, University of California Press, 2003, notably Chapter 3 on the promotion of family values by a Shanghainese entrepreneur.

70. See Robert Gardella, Jane K. Leonard and Andrea McElderry (eds.), Chinese Business History: Interpretive Trends and Priorities for the Future, Armonk, New York, M.E. Sharpe, 1998, in particularl Albert Feuerwerker's chapter, “Doing Business in China over Three Centuries", pp. 16-34.

71. Marie-Claire Bergère. The Golden Age of the Chinese Bourgeoisie, 1911-1937, Cambridge, Mass., Cambridge University Press, 1989.

\section{RÉSUMÉS}

This article looks at an economic organisation more and more frequently seen in China: the private family firm. Through an analysis of the way Mao Lixiang speaks of his career, of family firms and of the Chinese economy in general, the article aims to clarify this new and growing ideological and moral order. The use of a rhetoric at the same time modernist, socialist, Confucian and traditional reflects the opportunism of the man himself and the mixing and matching of values that characterises China today. 